\title{
DNA : DNA Hybridization Studies of Rhizobium japonicum and Related Rhizobiaceae
}

\author{
By A. B. HOLLIS, ${ }^{1}$ W. E. KLOOS ${ }^{2}$ AND G. H. ELKAN ${ }^{1 *}$ \\ ${ }^{1}$ Department of Microbiology and ${ }^{2}$ Department of Genetics, North Carolina State University, \\ Raleigh, North Carolina 27650, U.S.A.
}

(Received 24 July 1980; revised 6 October 1980)

The symbiotic nitrogen-fixing bacteria associated with soybeans (Glycine max) have been classified routinely as Rhizobium japonicum. DNA:DNA hybridization studies were conducted to estimate the genetic relationships of strains labelled as $R$. japonicum to clarify their taxonomic status. Reassociation reactions were carried out using DNA from various Rhizobium and Agrobacterium species. Relationships of DNA sequences were also estimated by comparing the thermal stability of heterologous DNA duplexes with that of the homologous DNA duplex. The results indicated that strains labelled as $R$. japonicum can be separated into at least three DNA homology groups. Reference strains of other Rhizobium species, with the exception of $R$. lupini, were not closely related to these homology groups.

\section{INTRODUCTION}

The present classification of Rhizobium, the symbiotic nitrogen-fixing bacteria, is based on cross-inoculation between the bacteria and their various legume hosts and results in the designation of six species: Rhizobium meliloti, $R$. trifolii, $R$. phaseoli, $R$. lupini, $R$. leguminosarum and $R$. japonicum. This scheme, originally proposed by Fred et al. (1932), has been inadequate from the time of its acceptance due to inconsistencies. For example, $R$. japonicum, which was given a separate species status due to its nodulation of soybeans, was later found to infect some other legumes nodulated by other rhizobia. In addition, other groups were entirely excluded from classification by this system, such as the 'cowpea' group, which is promiscuous (Lange, 1961).

In the species $R$. japonicum, comparisons of the guanine + cytosine content in DNA have indicated a range of values from 61 to $64 \mathrm{~mol} \%$ (Elkan \& Usanis, 1971). However, within this relatively narrow range, strains could be arranged into at least two clearly separated clusters of values which, when converted to maximum percentage DNA homology, suggested the presence of two moderately divergent groups.

Relationships among strains may also be suggested by their specific antigenic properties. In this regard, the serological profile of $R$. japonicum indicated a high degree of antigenic heterogeneity (Date, 1962).

The results of some relatively recent genetic exchange experiments (Johnston \& Beringer, 1977) and DNA :DNA hybridization studies (Gibbons \& Gregory, 1972; Heberlein et al., 1967; Jarvis et al., 1980) support the need for reconsideration of the current Rhizobium classification. In this investigation, we have determined the DNA sequence relationships of strains labelled as $R$. japonicum and some 'cowpea' rhizobia. 
Table 1. Rhizobium and Agrobacterium strains tested

\begin{tabular}{|c|c|c|c|}
\hline Organism & Source* & Organism & Source* \\
\hline . japonicum & & R. trifolii & \\
\hline $61 \mathrm{~A} 50$ & Nitragin Co., U.S.A. & ATCC 14480 & ATCC \\
\hline $61 \mathrm{~A} 76$ & Nitragin Co., U.S.A. & & \\
\hline USDA 86 & USDA & R. meliloti & \\
\hline USDA 24 & USDA & ATCC 9930 & ATCC \\
\hline USDA 29 & USDA & & \\
\hline USDA 110 & USDA & R. leguminosarum & \\
\hline USDA 76 & USDA & ATCC 10004 & ATCC \\
\hline USDA 140 & USDA & ATCC 10314 & ATCC \\
\hline USDA 31 & USDA & & \\
\hline USDA 46 & USDA & R. lupini & \\
\hline USDA 38 & USDA & ATCC 10319 & $\mathrm{ATCC}$ \\
\hline USDA 123 & USDA & AIC 10019 & \\
\hline USDA 62 & USDA & & \\
\hline USDA 94 & USDA & R.phaseoli & \\
\hline USDA 58 & USDA & $127 \mathrm{~K} 14$ & Nitragin Co., U.S.A. \\
\hline USDA 115 & USDA & ATCC 14482 & ATCC \\
\hline USDA 130 & USDA & & \\
\hline USDA 122 & USDA & Rhizobium sp. & \\
\hline USDA 117 & USDA & $32 \mathrm{H} 1$ & Nitragin Co., U.S.A. \\
\hline 5631 & W. R. Grace Co., U.S.A. & SMS-2 & Inst. Agronomico, Brazil \\
\hline 5633 & W. R. Grace Co., U.S.A. & $3 \mathrm{G} 4 \mathrm{~b} 4$ & USDA \\
\hline THA6 & Texas A \& M Univ., U.S.A. & & \\
\hline $8^{\circ}$ & Iowa State Univ., U.S.A. & A. tumefaciens & \\
\hline 505 & Univ. Wisconsin, U.S.A. & A 80 & Univ. N. Carolina, U.S.A. \\
\hline 508 & Univ. Wisconsin, U.S.A. & B208 & Univ. N. Carolina, U.S.A. \\
\hline ATCC 10324 & ATCC & & \\
\hline D193 & CRIPP, Czechoslovakia & A. radiobacter & \\
\hline D209 & CRIPP, Czechoslovakia & 6467 & Univ. N. Carolina, U.S.A. \\
\hline
\end{tabular}

* ATCC, American Type Culture Collection, Rockville, Md., U.S.A.; CRIPP, Central Research Institute for Plant Production, Prague, Czechoslovakia: W. R. Grace Co., Princeton, Ill., U.S.A.; Instituto Agronomico, Campinas, Brazil; Iowa State University, Ames, lowa, U.S.A.; Nitragin Co., Milwaukee, Wis., U.S.A.; Texas A \& M University, College Station, Tex., U.S.A.; University of North Carolina, Chapel Hill, N.C., U.S.A.; University of Wisconsin, Madison, Wis., U.S.A.; USDA, US Department of Agriculture, Beltsville, Md., U.S.A.

\section{METHODS}

Bacteria and growth conditions. The Rhizobium strains used in these studies were obtained from several sources (Table 1). The $R$. japonicum, 'cowpea' and $R$. lupini species were maintained by routine transfer on an agar medium containing HEPES ( $N$-2-hydroxyethylpiperazine- $N$ '-2-ethanesulphonic acid) and MES [2-( $N$ morpholino)ethanesulphonic acidl, a variety of salts and gluconate, designated HMG (Cole \& Elkan, 1973). The remaining Rhizobium species were grown on yeast extract mannitol (YEM) agar (Lillich \& Elkan, 1968). Agrobacterium strains were maintained on nutrient agar and were cultured in nutrient broth medium. Stock slants were stored at $4{ }^{\circ} \mathrm{C}$ and transferred monthly to fresh slants. The $R$. japonicum strains were also cultured on solid medium plates for confirmation of colony morphologies. Production of nodules on legumes was verified for each of the Rhizobium species used. The authenticity of the R. japonicum strains was further verified by phage typing.

For inocula, the $R$, japonicum strains were grown in $10 \mathrm{ml} \mathrm{HMG} \mathrm{broth} \mathrm{in} 50 \mathrm{ml}$ DeLong flasks and were incubated on a gyrotary shaker at 28 to $30^{\circ} \mathrm{C}$ for $4 \mathrm{~d}$. Two transfers in a similar medium were made before the cultures were used as inocula. Negative growth response on LB medium (Miller, 1972) was used as a control for culture purity: this medium contains $1 \% \mathrm{NaCl}$ to inhibit growth of rhizobia.

Media and stock solutions. The HMG broth medium employed for labelling DNA of cells contained carrier-free $\mathrm{H}_{3}{ }^{32} \mathrm{PO}_{4}\left(5 \mathrm{mCi}^{-1}\right)$. The HMG broth is a synthetic buffering system unaffected by deletion or addition of small quantities of phosphates. The medium was adjusted to $\mathrm{pH} 6.8$ to 7.0 prior to sterilization. The radioisotope was added to inoculated media at early-exponential phase $\left(48 \mathrm{~h}\right.$ growth) during incubation at 28 to $30^{\circ} \mathrm{C}$. Cultures were then shaken in the presence of the radioisotope for an additional $48 \mathrm{~h}$. Unlabelled cells were grown in HMG broth for a total of $4 \mathrm{~d}$ under similar conditions to labelled cells but without the addition of radioisotope. 
Cell lysis and isolation of DNA. Cell lysis was initiated by the addition of sodium dodecyl sulphate (final concentration $2 \%, \mathrm{w} / \mathrm{v})$ to $25 \mathrm{ml}$ of buffered saline-EDTA $(0.15 \mathrm{M}-\mathrm{NaCl}, 0.1 \mathrm{M}$-EDTA, pH 8.0) cell suspension. The suspension was placed in a $60^{\circ} \mathrm{C}$ water bath for $10 \mathrm{~min}$, followed by cooling at room temperature. The DNA released was isolated and purified by a modification of the procedures of Brenner et al. (1969) as reported by Kloos \& Wolfshohl (1979).

DNA reassociation reactions. In most experiments, $0.1 \mu \mathrm{g}$ of sheared, heat-denatured, ${ }^{32} \mathrm{P}$-labelled DNA was allowed to react with $120 \mu \mathrm{g}$ of sheared, heat-denatured, unlabelled DNA in $1 \mathrm{ml}$ of $0.28 \mathrm{M}$-phosphate buffer, (PB, a buffer solution containing equimolar quantities of $\mathrm{Na}_{2} \mathrm{HPO}_{4}$ and $\mathrm{NaH}_{2} \mathrm{PO}_{4}$ ) at 65 or $80^{\circ} \mathrm{C}$ (non-restrictive and restrictive conditions, respectively). At the termination of reactions, unreacted, single-stranded DNA was separated from reassociated, double-stranded DNA on hydroxyapatite by the batch procedure described by Brenner and co-workers $(1969,1972,1976)$. The concentration of unlabelled DNA and reaction incubation time were selected to provide nearly maximal reassociation of labelled DNA with unlabelled DNA $(56 \pm 5 \%$ in homologous reactions). The concentration of labelled DNA was small enough to prevent significant reassociation of labelled DNA fragments with one another $(<4 \%)$. The percentage relative binding was determined by normalizing the amount of DNA bound on hydroxyapatite in heterologous reactions to that bound in homologous reactions. For determining the thermal stability of DNA duplexes, reassociated DNA prepared at $65^{\circ} \mathrm{C}$ and adsorbed on hydroxyapatite was eluted in a series of $0.14 \mathrm{M}-\mathrm{PB}$ washes at increasing $2.5^{\circ} \mathrm{C}$ increments from 65 to $100^{\circ} \mathrm{C}$ to produce a thermal elution profile. This profile was then used to determine the midpoint of thermal elution $\left(T_{m(e)}\right)$ of the hybridized DNA.

\section{RESULTS}

In order to clarify the genomic relationships of strains labelled as $R$. japonicum species, DNA :DNA hybridization studies were carried out to determine the relative binding of heterologous DNAs and thermal stability of DNA duplexes. Comparisons were also made between $R$. japonicum strains, other Rhizobium species and Agrobacterium species. Although the various $R$. japonicum strains were isolated from many geographical areas, the results indicated that the source of the various organisms was completely independent of the degree of genetic relatedness revealed throughout the reassociation experiments. As can be seen from the reassociation data (Table 2), strains labelled as $R$. japonicum fall into at least three distinct DNA homology groups. One of these groups, designated $R$. japonicum subspecies 1 or homology group I, contains both the $R$. japonicum reference strain ATCC 10324 and the $R$. lupini reference strain ATCC 10319, together with nine other strains labelled as $R$. japonicum. Another group, designated $R$. japonicum subspecies 2 or homology group Ia, containing $R$. japonicum USDA 110 and five other strains, is more closely related to homology group I (relative binding $51 \pm 7 \%$ at $65^{\circ} \mathrm{C}, 35 \pm 9 \%$ at $80^{\circ} \mathrm{C}$ ) than to the third group (relative binding $29 \pm 7 \%$ at $65^{\circ} \mathrm{C}, 11 \pm 5 \%$ at $80^{\circ} \mathrm{C}$ ) designated Rhizobium sp. or homology group II. The widely divergent homology group II is composed of $R$. japonicum $61 \mathrm{~A} 76$ and eight other strains. Several other strains labelled as $R$. japonicum and the 'cowpea' rhizobia have diverged significantly and may represent yet additional DNA homology groups.

Thermal elution profile data (not shown) indicated that the unpaired bases in duplexes formed between DNA of the reference strain $R$. japonicum ATCC 10324 and DNAs of $R$. japonicum D193 and $R$. lupini ATCC 10319 were no more than $1.0 \%$ of the total genome assayed. In contrast, the thermal elution profiles of heterologous DNA duplexes formed between $R$. japonicum, ATCC 10324 and USDA 31, 'cowpea' 32H1 and 61A76 displayed a $T_{m(e)}$ averaging over $10^{\circ} \mathrm{C}$ below that of the homologous $R$. japonicum ATCC 10324 DNA duplex, suggesting that more than $10 \%$ of the bases were mismatched; this is consistent with a separate species status. The moderate decrease in thermal stability $\left(\Delta T_{m(e)}=6{ }^{\circ} \mathrm{C}\right)$ observed for heterologous DNA duplexes formed by the reassociation of DNA of $R$. japonicum strains ATCC 10324, USDA 110 and $8^{\circ}$ may indicate an intermediate or subspecies relationship between $R$. japonicum ATCC 10324 of DNA homology group I and the above $R$. japonicum strains of DNA homology group Ia. The thermal stability results thus complemented the relative binding data used to delineate DNA homology groups. 


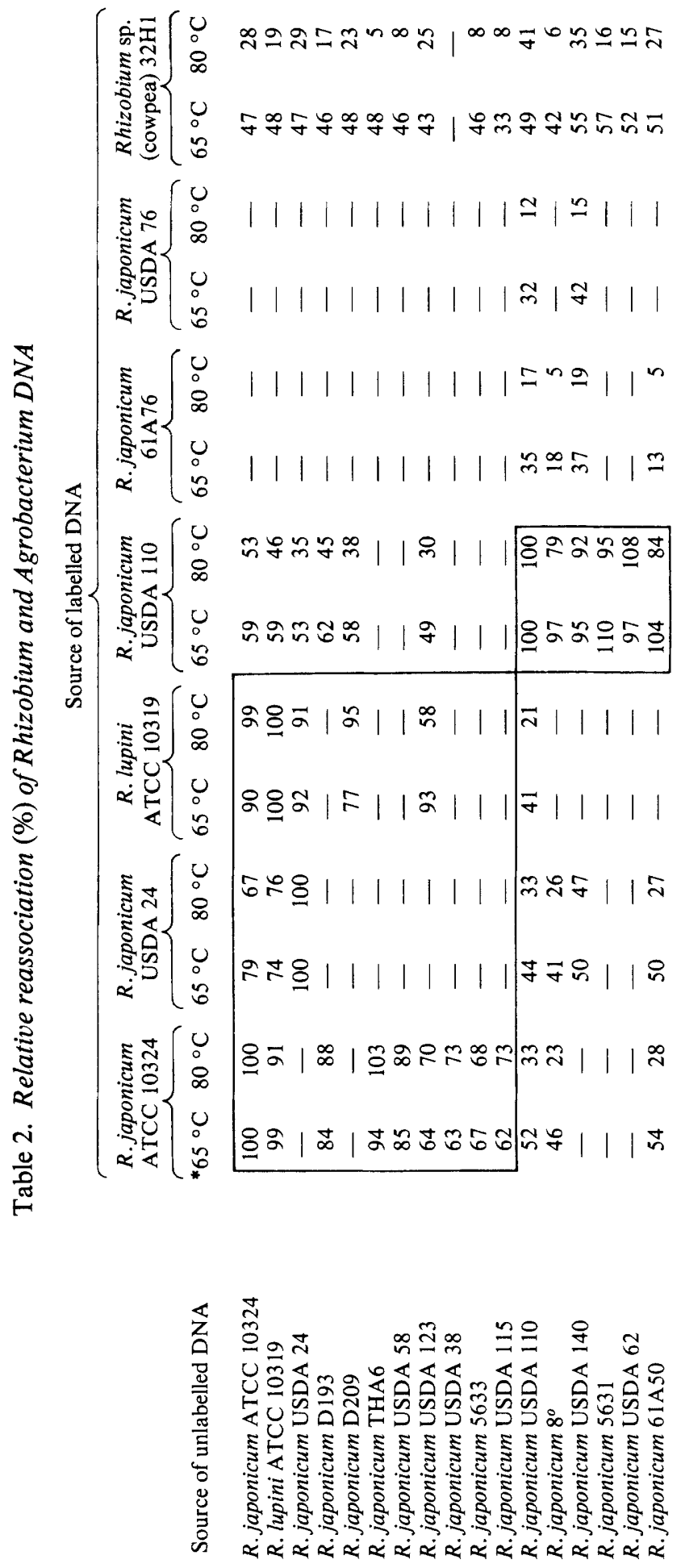




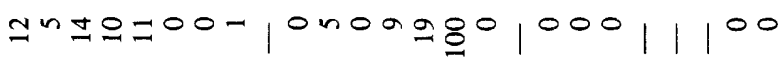

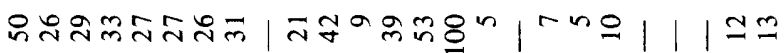

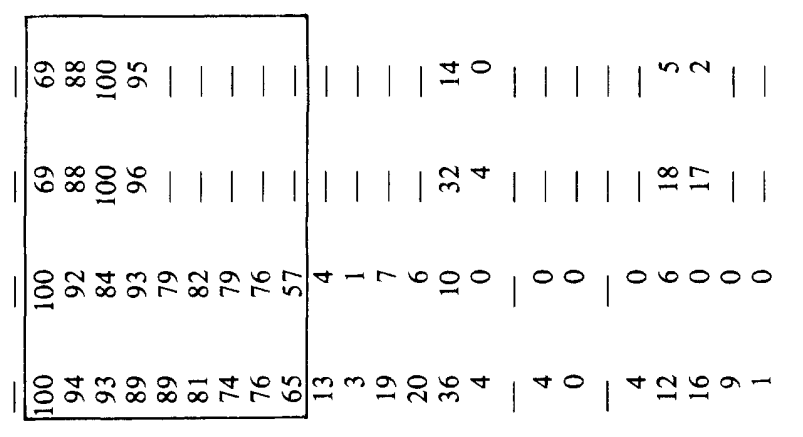

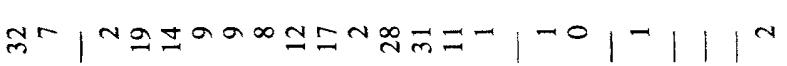

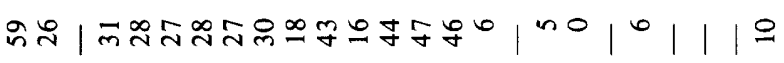

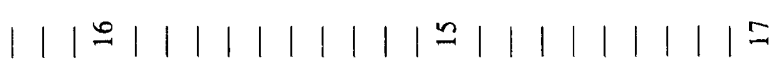
$\left|1^{a}\right| 1|1| 1|1| 121|1| 1|1| 1 \pi$

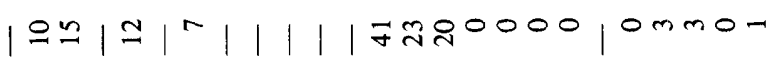
|

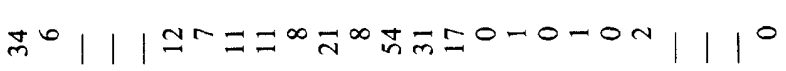

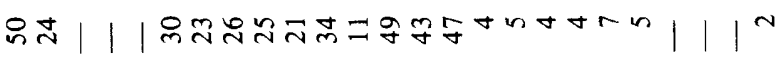

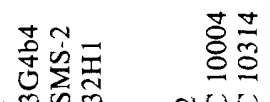

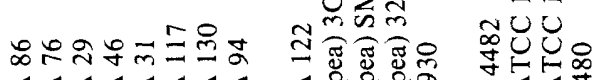

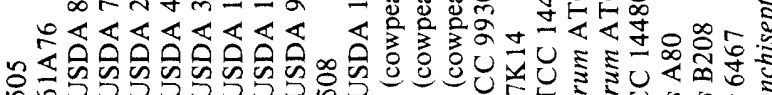

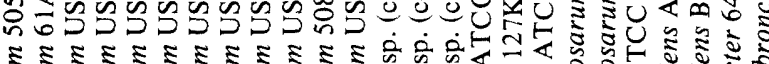

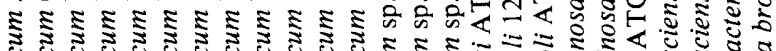

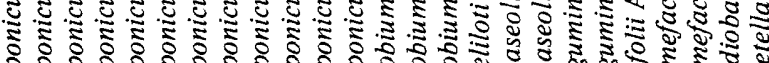

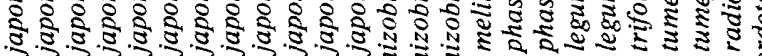

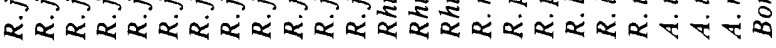




\section{DIS C US SION}

The separation of strains labelled as $R$. japonicum into at least three DNA homology groups shows the diversity of these bacteria and casts serious doubt on the validity of a single species designation for this group.

Hybridization data for Rhizobium strains 3G4b4 and SMS-2, both 'cowpea' rhizobia, and $R$. japonicum 505 fall within the possible limits of a borderline species or subspecies relationship to $R$. japonicum (DNA homology groups I and Ia). The above 'cowpea' strains are not as closely related to the 'cowpea' strain $32 \mathrm{H} 1$. It would appear that 'cowpea' rhizobia, like strains labelled as $R$. japonicum, may represent at least two different species. Due to the limited number of agrobacteria included in this study, it is difficult to evaluate the overall degree of similarity between Agrobacterium and Rhizobium. The three Agrobacterium strains examined demonstrated very little relationship to the rhizobia selected as sources of labelled DNA. Graham's (1964) data indicated a slight relatedness between the fast-growing rhizobia and Agrobacterium.

It is interesting to note that the $R$. lupini reference strain ATCC 10319 and $R$. japonicum reference strain ATCC 10324 are highly related as determined by reciprocal DNA reassociation reactions and the thermal stability of DNA duplexes. The $R$. lupini strain used is also closely related to several other $R$. japonicum strains (USDA 24, D209, USDA 123). Since only the single reference $R$. lupini strain was included in this study, we do not wish to

Table 3. Comparison of DNA homology and serological groups of strains labelled as Rhizobium japonicum

\begin{tabular}{|c|c|c|}
\hline & $\begin{array}{c}\text { DNA homology } \\
\text { group }\end{array}$ & $\begin{array}{l}\text { Serological } \\
\text { group* }\end{array}$ \\
\hline \multicolumn{3}{|c|}{ Group I } \\
\hline \multirow{10}{*}{$\begin{array}{l}\text { R.japonicum } \\
\text { subspecies } 1\end{array}$} & ATCC $10324 \dagger$ & 24 \\
\hline & USDA 24 & 24 \\
\hline & D 193 & 24 \\
\hline & D209 & 24 \\
\hline & THA6 & 76 \\
\hline & USDA 58 & 58 \\
\hline & USDA 123 & 123 \\
\hline & USDA 38 & 38 \\
\hline & 5633 & 123 \\
\hline & USDA 115 & $38-115$ \\
\hline \multicolumn{3}{|c|}{ Group Ia } \\
\hline \multirow{6}{*}{$\begin{array}{l}R . \text { japonicum } \\
\text { subspecies } 2\end{array}$} & USDA 110 & 110 \\
\hline & $8^{\circ}$ & 110 \\
\hline & USDA 140 & 62 \\
\hline & 5631 & 110 \\
\hline & USDA 62 & 62 \\
\hline & $61 \mathrm{~A} 50$ & 110 \\
\hline \multicolumn{3}{|c|}{ Group II } \\
\hline \multirow{9}{*}{ Rhizobium sp. } & $61 \mathrm{~A} 76$ & 31 \\
\hline & USDA 86 & 86 \\
\hline & USDA 76 & 76 \\
\hline & USDA 29 & 31 \\
\hline & USDA 46 & 46 \\
\hline & USDA 31 & 31 \\
\hline & USDA 117 & 76 \\
\hline & USDA 130 & 130 \\
\hline & USDA 94 & 94 \\
\hline
\end{tabular}


conclude now that $R$. lupini and $R$. japonicum should be combined in one species. An earlier suggestion that these species should be combined was made by Graham (1964) based on numerical taxonomic data. This view was consistent with the DNA base composition data of De Ley \& Rassel (1965). Other DNA:DNA hybridization studies (Gibbons \& Gregory, 1972 ) showed that several strains of $R$. lupini and $R$. japonicum were very closely related. We are expanding our studies to determine whether these two species should be combined or if perhaps the $R$. lupini reference strain is atypical of the species.

The fact that strains labelled as $R$. japonicum displayed considerable diversity in their nucleotide sequence relatedness becomes an important issue in Rhizobium research since results determined for a particular test strain may show considerable departure from the reference $R$. japonicum strain ATCC 10324. It is significant that many of the strains of $R$. japonicum fell into three different DNA homology groups and that two of these groups are so widely divergent that they probably represent different species. Originally, all of the $R$. japonicum strains used in this study were authenticated in nodulation tests, so on the basis of the 'cross-inoculation' concept and prevailing criteria, they were named appropriately. Obviously, the taxonomic status of $R$. japonicum needs re-evaluation. With only one possible exception, $R$. japonicum THA6, members of the same serological group are included in the same DNA homology group (Table 3 ). Should serological type remain a valid character predicting DNA relatedness in future work, this would afford ecologists with a simple test for identifying Rhizobium species.

Our results strongly indicate the inadequacy of the current classification of rhizobia based on cross-inoculation between the bacteria and their host legume. Not only does it appear that there is more than one species designated as $R$. japonicum but there is also an indication that $R$. lupini may not be a species different from $R$. japonicum. On the strength of these data, we have begun an extensive re-examination of the taxonomy of Rhizobium using DNA : DNA hybridization techniques.

This research was supported in part by grant 701-15-25 from the U.S. Department of Agriculture Cooperative State Research Service. Paper number 6394 of the Journal Series of the North Carolina Agricultural Research Service, Raleigh, North Carolina.

\section{REFERENCES}

Brenner, D. J., Fanning, G. R., Rake, A. V. \& JoHNSON, K. E. (1969). Batch procedure for thermal elution of DNA from hydroxyapatite. Analytical Biochemistry 28, 447-459.

Brenner, D. J., Fanning, G. R., Skerman, F. J. \& Falkow, S. (1972). Polynucleotide sequence divergence among strains of Escherichia coli and closely related organisms. Journal of Bacteriology 109, 953-965.

Brenner, D. J., Steigerwalt, A. G., Falcae, D. P., WeAver, R. E. \& FANNING, G. R. (1976). Characterization of Yersinia enterocolitica and Yersinia pseudotuberculosis by deoxyribonucleic acid hybridization and by biochemical reactions. International Journal of Systematic Bacteriology 26, 180-194.

Cole, M. A. \& Elkan, G. H. (1973). Transmissible resistance to penicillin G, neomycin, and chloramphenicol in Rhizobium japonicum. Antimicrobial Agents and Chemotherapy 4, 248-253.

DATE, R. A. (1962). Root nodule bacteria and legume relationships: studies on serological classification, competition effects, and survival and location in preinoculated seed. Doctoral thesis. Department of Bacteriology, University of Maryland, U.S.A.
DE LEY, J. \& RAssel, A. (1965). DNA base composition, flagellation and taxonomy of the genus Rhizobium. Journal of General Microbiology 41, 85-91.

Elkan, G. H. \& Usanis, R. A. (1971). Theoretical deoxyribonucleic acid homology between strains of Rhizobium japonicum. International Journal of Systematic Bacteriology 21, 295-298.

Fred, E. B., Baldwin, I. L. \& McCoy, E. (1932). Root Nodule Bacteria and Leguminous Plants. Madison: University of Wisconsin Press.

Gibbons, A. M. \& Gregory, K. F. (1972). Relatedness among Rhizobium and Agrobacterium species determined by three methods of nucleic acid hybridization. Journal of Bacteriology 111, 129141.

GrahaM, P. H. (1964). The application of computer techniques to the taxonomy of the root nodule bacteria of legumes. Journal of General Microbiology 35, 511-517.

Heberlein, G. T., De Ley, J. \& Tijtgat, R. (1967). Deoxyribonucleic acid homology and taxonomy of Agrobacterium, Rhizobium, and Chromobacterium. Journal of Bacteriology 94, 116-124. 
JARvis, B. D. W., Dick, A. G. \& Greenwood, R. M. (1980). Deoxyribonucleic acid homology among strains of Rhizobium trifolii and related species. International Journal of Systematic Bacteriology $\mathbf{3 0}$, 42-52.

Johnston, A. W. B. \& Beringer, J. E. (1977). Chromosomal recombination between Rhizobium species. Nature, London 267, 611-613.

KLoos, W. E. \& Wolfshohl, J. F. (1979). Evidence for deoxyribonucleotide sequence divergence between staphylococci living on human and other primate skin. Current Microbiology 3, 167-172.
LANGE, R. T. (1961). Nodule bacteria associated with the indigenous leguminosae of South-Western Australia. Journal of General Microbiology 26, 351-359.

Lillich, T. T. \& ElKaN, G. H. (1968). Evidence countering the role of polygalacturonase in invasion of root hairs of leguminous plants by Rhizobium spp. Canadian Journal of Microbiology 14, 617625.

MilleR, J. H. (1972). Experiments in Molecular Genetics. Cold Spring Harbor, New York: Cold Spring Harbor Laboratory. 